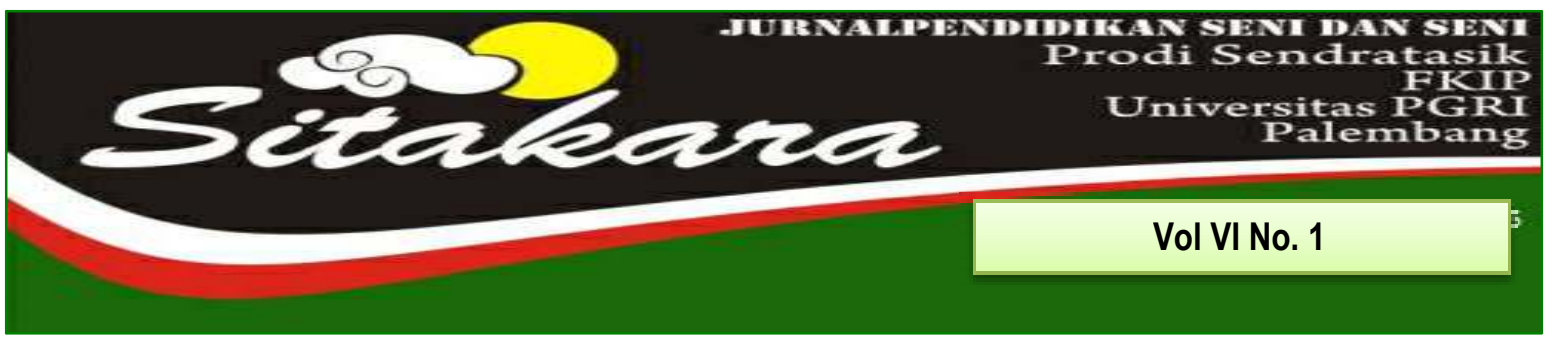

PERTUNJUKAN SOLIS MARIMBA DENGAN REPERTOAR THE VARIANTIONS ON THEME (FROM THE MALAY'S "PUCUK PISANG")

(Fery Herdianto)

BUKIT SIGUNTANG DALAM PENGEMBANGAN KONSEP RUANG KOREOGRAFI $\quad$ 13-26 LINGKUNGAN TARI

(Rully Rochayati, Eva Dina Chairunisa)

APLIKASI SIBELIUS SEBAGAI MEDIA PEMBELAJARAN DALAM MENULIS NOTASI MUSIK BERMAS

(Dedy Firmansyah \& Nugroho NAD)

PENGARUH MODEL PEMBELAJARAN EXPLICIT INSTRUCTION PADA 40-54 PEMBELAJARAN TARI DAERAH

(Treny Hera \& Efita Elvandari)

SIMBOLISASI ORNAMEN NAGA PADA PEMBATAS JALAN DI PALEMBANG (Decky Kunian \& A.Heryanto)

PENGARUH MODEL PEMBELAJARAN INSIDE-OUTSIDE-CIRCLE (IOC) TERHADAP WRITING SKILL DALAM TEKS MENULIS DRAMA DI SMP SETIA NEGARA PALEMBANG

(Sri Wahyu Indrawati \& Yuspar Uzer)

PEMANFAATAN TEKNOLOGI MULTIMEDIA DALAM PEMBELAJARAN MUSIK DI $79-87$ SMP N 1 PALEMBANG

(Novdaly Fillamenta \& Yuliza Aryani)

BENTUK PENYAJIAN ORKES GAMBUS SANGGAR MOZAIG PADA ACARA PERNIKAHAN ADAT ARAB PALEMBANG

(Auzy Madona Adoma)

PENINGKATAN KEMAMPUAN MEMBACA TEKS DRAMA DENGAN 100-111 MENGGUNAKAN METODE SPEED READING PADA PEMBELAJARAN BAHASA INDONESIA UNTUK SISWA SMPN 16 PALEMBANG (Wandiyo)

PELAKSANAAN EVALUASI PEMBELAJARAN SENI BUDAYA DI SMP 1 JEKULO 112-123 KUDUS PADA MASA PANDEMI COVID-19

M.Panji Wahyu Mukti \& Wahyu Lestari 
1. Naskah berbahasa Indonesia bertemakan Seni Budaya yang meliputi hasil penelitian pengajaran seni budaya, cabang seni, dan kebudayaan.

2. Naskah harus asli dan belum pernah dimuat dalam media lain. Naskah dapat berupa hasil penelitian perorangan atau kelompok.

3. Naskah ditulis dengan cara-cara yang sesuai dengan ketentuan penulisan artikel ilmiah menggunakan bahasa Indonesia yang baku, berupa ketikan, beserta soft line dalam CD-RW atau dengan mengirimkan email pada redaksi Jurnal SITARARA dengan alamat email: jurnalsitakarasendratasik@yahoo.com, spasi 1,5 jenis huruf Arrial Narrow ukuran 12, dengan panjang naskah antara 8-15 halaman pada kertas A4.

4. Artikel hasil penelitian memuat:

JUDUL

Nama Penulis

Abstrak

A. Pendahuluan

B. METODE PENELITIAN

C. HASIL DAN PEMBAHASAN

D. SIMPULAN
: XXX (HURUF KAPITAL)

: (disertai jabatan dan institusi)

: (Bahasa Indonesia yang memuat 100150 kata diikuti kata kunci, dengan jenis huruf Arrial Narrow dan ukuran huruf 11 spasi tunggal serta dicetak miring)

: (Memuat latar belakang masalah, tinjauan pustaka secara ringkas, masalah penelitian dan tujuan penelitian)

: (Berisi simpulan)

5. Artikel kajian konseptual memuat:

JUDUL

Nama Penulis

Abstrak

\section{: XXX (HURUF KAPITAL)}

: (disertai jabatan dan institusi)

: (Bahasa Indonesia yang memuat 100150 kata diikuti kata kunci, dengan jenis huruf Arrial Narrow dan ukuran huruf 11 serta dicetak miring)

PENDAHULUAN
: (Memuat latar belakang masalah, tinjauan pustaka secara ringkas, masalah penelitian dan tujuan penelitian) 
Sub Judul

Sub Judul

SIMPULAN

DAFTAR PUSTAKA
: Sesuai dengan kebutuhan (tanpa numbering)

: (Berisi simpulan dan saran)

: (Berisi pustaka yang dirujuk dalam uraian naskah

6. Referensi sumber dalam teks artikel ditulis dengan menggunakan side note, contoh: (Jalalluddin, 1991:79); (Taufik, 2005;350); (Hamid dan Madjid, 2011:43). Sementara penulisan daftar pustaka disusun dengan ketentuan. Nama Pengarang. Tahun Terbit. Judul (dicetak miring). Kota Terbit: Nama Penerbit. Contoh: Koentjaraningrat. 2010. Manusia dan Kebudayaan Di Indonesia. Jakarta: Djambatan.

Daftar pustaka hanya memuat pustaka/sumber yang dirujuk dalam uraian dan disusun menurut abjad, tanpa nomor urut.

7. Naskah yang dimuat akan disunting kembali oleh redaksi tanpa mengubah isinya.

8. Naskah yang ditolak (tidak bisa dimuat) akan dikirim kembali ke penulis dengan pemberitahuan tertulis dari redaksi atau alamat email.

9. Penulis yang naskahnya dimuat akan mendapatkan 1 (satu) majalah nomor yang bersangkutan.

10. Contact Person: Treny Hera (085357344704) dan Mainur (081373165553). 


\title{
PENINGKATAN KEMAMPUAN MEMBACA TEKS DRAMA DENGAN MENGGUNAKAN METODE SPEED READING PADA PEMBELAJARAN BAHASA INDONESIA UNTUK SISWA SMPN 16 PALEMBANG
}

\author{
Oleh: \\ Wandiyo \\ (Dosen FKIP Universitas PGRI Palembang) \\ Email:wandiyo67@gmail.com
}

\begin{abstract}
ABSTRAK
Penelitian ini bertujuan mengkaji Peningkatan Kemampuan Membaca Teks Drama dengan Menggunakan Metode Speed Reading Pada Pembelajaran Bahasa Indonesia untuk Siswa SMPN 16 Palembang. Berdasarkan pembatasan masalah di atas adalah Bagaimanakah Peningkatan Kemampuan Membaca Teks Drama dengan Menggunakan Metode Speed Reading Pada Pembelajaran Bahasa Indonesia untuk Siswa SMPN 16 Palembang?. Hasil penelitian ini memperkuat pernyataan Johnson dan Pearson (dalam Zuchdi, 2008: 23-24) bahwa faktor yang berasal dari dalam diri dan faktor yang berasal dari luar pembaca dapat mempengaruhi terhadap kemampuan membaca pemahaman. Lebih lanjut, hasil penelitian ini juga selaras dengan pernyataan Paul D. Leedy (dalam Soedarso, 2005: 120-121) yang mengemukakan beberapa tujuan membaca pemahaman. Tujuan tersebut antara lain: untuk mengerti ide pokok, mampu memahami fakta dan detail khusus, meningkatkan kekayaan pengetahuan umum, dan mendapatkan informasi tentang apa yang terjadi di dunia.
\end{abstract}

Kata Kunci: Peningkatan Kemampuan Membaca Teks Drama, Metode Speed Reading, Belajaran Bahasa Indonesia

\section{A. PENDAHULUAN}

Pembelajaran bahasa mencakup

empat aspek keterampilan berbahasa yaitu mendengarkan, berbicara, membaca, dan menulis (Tarigan, 2008:

1). Secara karakteristik, keempat keterampilan itu berdiri sendiri, namun dalam penggunaan bahasa sebagai proses komunikasi tidak dapat dipisahkan satu dengan yang lain dan harus mendapatkan porsi yang seimbang serta dilaksanakan secara terpadu. Hal ini menunjukkan bahwa bahasa merupakan keterpaduan dari beberapa aspek. Salah satu aspek keterampilan berbahasa yang terdapat dalam materi pembelajaran bahasa Indonesia di sekolah menengah kelas VII adalah keterampilan membaca. Keterampilan membaca selalu ada dalam setiap tema pembelajaran. Hal tersebut membuktikan pentingnya 
penguasaan keterampilan membaca. Nurgiyantoro (2010, p. 368), menyatakan bahwa kegiatan membaca merupakan aktivitas berbahasa yang bersifat reseptif kedua setelah menyimak. Disebut reseptif karena dengan membaca seseorang akan memperoleh informasi yang dapat membuka dan memperluas dunia dan horison seseorang. Menurut Soedarso (2005: 4) membaca adalah aktivitas yang kompleks dengan mengerahkan sejumlah besar tindakan terpisah-pisah, mencakup penggunaan pengertian dan khayalan, pengamatan, dan ingatan. Manusia tidak mungkin dapat membaca tanpa menggerakkan mata dan menggunakan pikiran. Membaca merupakan keterkaitan antara fisik dan mental. Secara fisik membaca memerlukan indra penglihatan dan secara mental membaca memerlukan pemahaman dan daya ingat. Seseorang dapat membaca dengan baik jika mampu melihat huruf-huruf dengan jelas, mengingat lambang-lambang bahasa dengan tepat, dan memiliki penalaran yang cukup untuk memahami bacaan. Kemampuan membaca merupakan salah satu kunci menuju kemajuan siswa. Pada kenyataannya, masih banyak siswa yang tidak menikmati apa yang dibacanya. Abdurahman (1996: 171) menyatakan bahwa banyak anak yang dapat membaca secara lancar suatu bahan bacaan tetapi tidak memahami isi bacaan tersebut. Oleh karena itu, minat baca menjadi berkurang, karena membaca dianggap pekerjaan yang membosankan. Berdasarkan fenomena tersebut kegiatan membaca harus diikuti dengan pemahaman tentang hal yang dibaca dengan kata lain harus ada pemahaman membaca. Sebagaimana hasil pengukuran yang dilakukan oleh PISA atau Proggramme for International Student Assestment tahun 2006 (Fuady, Amir, Sumarwati, dan Slamet Mulyono, 2012: 1), yakni suatu survei terhadap literasi membaca pada siswa usia SMP dari berbagai negara, menunjukkan kemampuan membaca siswa Indonesia ada di urutan 48 dari 56 negara. Hal ini merupakan posisi terendah untuk negara-negara di kawasan Asia Tenggara. Rendahnya kemampuan siswa menjadi sebuah petunjuk adanya kelemahan dan kesulitan belajar membaca pemahaman.

Berdasarkan hasil observasi diketahui bahwa nilai siswa di SMPN 16 Palembang belum maksimal karena masih banyak siswa yang kurang dalam 
membaca serta menyimaknya, hal ini disebabkan oleh guru yang masih monoton saat melakukan proses pembelajaran sehingga perkembangan siswa didalam pembelajaran sangat berkurang. Dengan menggunakan metode Speed Reading ini kemampuan membaca serta menyimak siswa menjadi lebih maksimal. Pelajaran Bahasa Indonesia merupakan mata pelajaran yang harus dilaksanakan oleh pelajar di Negara Indonesia dan bersifat wajib. Pada hakikinya pembelajaran bahasa Indonesia diarahkan agar meningkatkan kompetensi siswa saat berkomunikasi, sarana berfikir, sarana menemukan ide atau gagasan dan sebagai sarana untuk berekspresi, (Maryanti, 2017). Di dalam kehidupan setiap hari bahasa Indonesia selalu digunakan sebagai alat komunikasi di Indonesia oleh sebab itu, mata pelajaran bahasa Indonesia diajarkan sehingga siswa mampu serta bisa berkomunikasi secara lisan maupun tertulis dengan berbagai aspek secara efektif dan efisien. Terdapat empat keterampilan berbahasa yang diajarkan di seluruh sekolah yang ada di Indonesia di antaranya meliputi keterampilan menyimak, keterampilan membaca, keterampilan berbicara, serta keterampilan menulis. Keterampilan terbagi menjadi dua bagian yakni suatu keterampilan bersifat menerima (reseptif) melingkupi keterampilan menyimak dengan membaca, lalu keterampilan bersifat mengungkapkan (produktif) serta meliputi keahlian menulis dan membaca, (Hariyanto, 2011). Kemampuan merupakan kesanggupan atau kecakapan orang dalam menguasai suatu keahlian yang merupakan bawaan sejak lahir, hasil latihan atau praktik dan digunakan untuk mengerjakan sesuatu yang ditjukan melalui tindakan, (Widyaningrum, 2019). Makna membaca secara umum sangatlah luas, istilah 'membaca' dapat dikatakan sebagai 'melihat, memahami, mengeja, serta mengucapkan isi' dari bacaan. Kemampuan membaca yang dimiliki oleh semua siswa merupakan suatu kemampuan awal yang sangat penting serta harus dikembangkan melalui kreativitas berfikir. Hal ini dipertegas oleh pendapat menurut Rahim, 2008 yang mengatakan bahwa kemampuan membaca yang perlu dikuasai oleh seluruh siswa di SMP karena seluruh proses belajar siswa berkaitan dengan kemampuan membaca. Membaca merupakan suatu aktivitas dalam 
berbahasa yang memiliki peranan penting untuk kehidupan manusia salah satunya untuk mencari informasi atau pengetahuan yang sangat dibutuhkan manusia. Membaca ialah proses yang ditujukan kepada pembaca guna mendapatkan amanat yang ingin disampaikan oleh penulis melalui sarana kata-kata atau bahasa tertulis, (Dewantara, 2015). Menurut Dalman (2014), mengatakan bahwa langkah awal anak diperkenalkan dengan huruf, abjad serta melafalkannya. Kemudian siswa diajarkan 13 dengan cara mengeja sukusuku kata, serta membaca beberapa kalimat-kalimat pendek. Siswa yang kurang dan tidak diajarkan untuk berlatih membaca sejak dini akan akan mengalami berbagai kesulitan dalam belajar. Hal ini dipertegas oleh pendapat menurut Inawati dan Doni Sanjaya (Slamet, 2009).

Kesulitan belajar dipengaruhi' oleh 'berbagai 'faktor antara lain : 1 . Penekanan terhadap bahan pembelajaran yang terlalu teoritis 2 . Kurangnya bentuk kegiatan mudah dalam membina sebagai peningkatkan kemampuan membaca 3. Pemilihan bahan ajar serta pemaparan strategi yang dilakukan oleh guru masih kurang tepat 4. Bahan pembelajaran yang digunakan untuk proses belajar mengajar kurang memadai 5 . Rendahnya kemampuan siswa dalam membaca yang disebabkan oleh kurang berlatih sehingga pemahaman siswa tidak mencapai batas minimun. Terdapat beberapa kebiasaan membaca yang tidak efisien, antara lain : 1. Membaca dengan mengeluarkan suara 2 . Membaca perkata demi kata 3 . Membaca menggunakan alat untuk menunjuk baris bacaan. 4. Selalu membaca serta melakukan gerak pada anggota tubuh 5. Membaca dengan berbisik atau bersenandung 6 . Keterbiasaan membaca kemudian berhenti pada setiap awal kalimat atau pada tengah-tengah kalimat 7 . Keterbiasaan dengan selalu mengulangi bacaan yang sudah dibaca. Menurut Romansyah dalam (Dalman : 2014).

Untuk meningkatkan kemampuan membaca pemahaman siswa, ada beberapa metode, antara lain metode Speed Reading yang dapat diterapkan dalam pembelajaran. Peningkatan kemampuan membaca menggunakan metode Speed Reading pada pembelajaran bahasa Indonesia menunjukan peningkatan membaca 
menggunakan metode Speed Reading untuk meningkatkan kemampuan membaca siswa mengalami peningkatan sehingga siswa memiliki perkembangan didalam pembelajaran dan proses pembelajaran akan jauh lebih maksimal. Langkah-langkah dalam membaca cepat antara lain : (1) Bacalah kata yang dirasa penting dan mencakup keseluruhan isi dari bacaan, misalnya judul dengan sub judul. Tafsirkan sesuai dengan imajinasi serta pengalaman yang telah dialami (2) Selalu perhatikan terlebih dahulu tentang keterangan gambar dari bacaan yang sedang dibaca (3) Baca kata yang diperlukan saja, didalam satu kalimat hanya ada satu ide pokok yang berada di kalimat utama pada paragraf masingmasing (4) Pikirkan kembali informasi yang telah diterima dari bacaan. Pada tahap ini siswa telah memahami isi bacaan dan telah mendapatkan informasi yang dicari, (Uzer, 2016).

Berdasarkan latar belakang di atas, maka peneliti akan mengkaji Peningkatan Kemampuan Membaca Teks Drama dengan Menggunakan Metode Speed Reading Pada Pembelajaran Bahasa Indonesia untuk Siswa SMPN 16 Palembang. Berdasarkan pembatasan masalah di atas adalah Bagaimanakah Peningkatan Kemampuan Membaca Teks Drama dengan Menggunakan Metode Speed Reading Pada Pembelajaran Bahasa Indonesia untuk Siswa SMPN 16 Palembang?

\section{B. METODE PENELITIAN}

Jenis Metode penelitian yang digunakan dalam penelitian ini adalah Penelitian Tindakan Kelas (PTK). Arikunto $(2009$, p. 3) menyatakan bahwa penelitian tindakan kelas merupakan suatu pencermatan terhadap kegiatan belajar berupa tindakan, yang sengaja dimunculkan dan terjadi dalam sebuah kelas secara bersama-sama. Desain PTK di sini menggunakan model yang dikembangkan oleh Kemmis dan McTaggart. Terdapat empat aspek pokok yang terdapat dalam penelitian tindakan menurut Kemmis dan McTaggart (dalam Madya, 2009: 59) yakni: (1) penyusunan rencana, (2) tindakan, (3) observasi, dan (4) refleksi. Madya (2009: 59) menyatakan bahwa rencana penelitian tindakan merupakan tindakan yang tersusun. Rencana bersifat fleksibel untuk dapat diadaptasikan dengan pengaruh yang terjadi secara tidak terdugadan kendala yang sebelumnya 
tidak terlihat. Rencana disusun berdasarkan hasil pengamatan awal yang reflektif. Tindakan yang dimaksud di sini adalah tindakan yang dilakukan secara sadar dan terkendali, yang merupakan variasi praktik yang cermat dan bijaksan serta mengandung inovasi. Implementasi tindakan mengarah pada perencaan yang telah dibuat sebelumnya, tujuannya agar pembelajaran berlangsung sesuai dengan yang direncanakan.

\section{HASIL DAN PEMBAHASAN}

Aminuddin (2002:31) mengemukakan bahwa sastra memiliki potensi yang besar untuk membawa masyarakat ke arah perubahan, termasuk perubahan karakter. Selain mengandung keindahan, sastra juga memiliki nilai manfaat bagi pembaca. Segi kemanfaatan muncul karena penciptaan sastra berangkat dari kenyataan sehingga lahirlah suatu paradigma bahwa sastra yang baik menciptakan kembali rasa kehidupan. Sebagai wujud untuk menyampaikan atau menginjeksikan pendidikan karakter dalam sastra kepada peserta didik ada beberapa upaya yang bisa dilakukan oleh pendidik. Pendidik mengungkapkan nilai-nilai dalam mata pelajaran bahasa dan sastra Indonesia dengan pengintegrasian langsung nilai-nilai karakter yang menjadi bagian terpadu dari mata pelajaran tersebut. Pendidik bisa menggunakan perbandingan cerita pendek berdasarkan kehidupan atau kejadian-kejadian dalam hidup para peserta didik kemudian mengubah halhal yang bersifat negatif dalam cerita pendek tersebut menjadi nilai positif. Dengan ini peserta didik mampu mengambil secara langsung nilai-nilai pendidikan karakter yang tersirat dan tersurat dalam tugas yang diberikan pendidik tadi karena merupakan bagain dari kehidupan peserta didik itu sendiri. Atau bisa juga menggunakan cerita untuk memunculkan nilai-nilai karakter dengan menceritakan kisah hidup orang-orang besar. Dengan kisah nyata yang dialami orang-orang besar dan terkenal bisa menjadikan peserta didik akan terpikat dan mengidolakan serta pastunya ingin menjadi seperti idolanya tersebut. Puisi (lagu) memberikan efek yang sangat dalam bagi pendengarnya. Bahkan kabar terkini yang telah kita ketahui bersama, bayi dalam kandungan pun bisa dipengaruhi dengan lagu yang diputar dekat dengan perut ibunya. Dengan 
dasar ini pendidik bisa menggunakan lagu-lagu dan musik (musikalisasi puisi) untuk mengintegrasikan nilai-nilai karakter dalam benak peserta didik. Pendidik bisa juga menggunakan drama sebagai media untuk melukiskan kejadiankejadian yang berisikan nilainilai karakter. Sehingga secara audio visual serta aplikasi langsung (pementasan drama) menjadikan peserta didik lebih mudah untuk memahami dan menyerap nilai-nilai karakter tersebut. Selain itu tugas-tugas yang bisa dikerjakan dirumah dapat mengambil contoh tentang apa yang dilihat peserta didik di televisi kemudian pendidik akan menjelaskan sekaligus meluruskan nilainilai apa saja yang ada dalam film di televisi tersebut. Ini akan lebih menggoreskan dalam-dalam nilai-nilai pendidikan karakter yang didapat di benak peserta didik.

\section{- Kemampuan Membaca}

Kemampuan membaca memiliki peranan penting dalam kehidupan mannusia. Seseorang yang memiliki kemampuan membaca tentu akan dapat berkomunikasi dengan bahasa tulis. Bahkan dengan kemampuan membaca, seseorang mampu menggali informasi, menambah wawasan, dan memperdalam ilmu pengetahuan. Namun, tidak semua orang mampu membaca dengan pemahaman yang baik. Kemampuan membaca pemahaman merupakan seperangkat keterampilan pemerolehan pengetahuan yang digeneralisasikan, yang memungkinkan orang memperoleh dan mewujudkan informasi yang diperoleh sebagai hasil membaca bahasa tertulis (Bormouth dalam Zuchdi, 2008: 22). Untuk memperoleh pemahaman yang tepat tentang suatu bacaan, pembaca harus memanfaatkan informasi yang telah dimilikinya, yakni informasi yang diperoleh selama menjalani kehidupan, hasil bacaan sebelumnya, dan sumbersumber informasi lainnya. Kesempurnaan hasil membaca siswa dapat tercapai, jika siswa mampu menghubungkan informasi baru yang ada dalam bacaan dengan latar belakang atau pengetahuan yang telah dimilikinya. 10 Membaca pemahaman merupakan bagian dari membaca telaah isi. Dalam menelaah isi suatu bacaan dituntut suatu ketelitian, pemahaman, kekritisan berpikir serta keterampilan menangkap ide-ide yang tersirat dalam bacaan. Tarigan (2008: 9-10) mengungkapkan bahwa membaca 
pemahamanadalah sejenis membaca yang bertujuan untuk memperoleh perincian-perincian atau fakta-fakta (reading for details or facts), memperoleh ide-ide utama (reading for main ideas), mengetahui urutan atau susunan organisasi cerita (reading for sequence or organization), menyimpulkan atau membaca inferensi (reading for inference), dan lain-lain. Tujuan membaca juga dikemukakan oleh Paul D. Leedy (dalam Soedarso, 2005: 120121) di antaranya yaitu, untuk mengerti ide pokok, memahami fakta dan detail khusus, meningkatkan kekayaan pengetahuan umum, mendapatkan informasi tentang apa yang terjadi di dunia, dan lain-lain. Penjelasan tersebut menunjukkan bahwa tujuan membaca pemahaman adalah untuk mendapatkan informasi dengan cara mencari ide pokok atau gagasan utama dalam suatu bacaan sehingga dapat memahami maksud dari bacaan tersebut. Selain itu, membaca juga dapat menambah wawasan pengetahuan tentang segala sesuatu yang terjadi di dunia.

\section{- Metode Speed Reading}

Speed Reading dalam bahasa inggris berarti membaca cepat. Menurut Nurhadi (2005) dalam bukunya bagaimana meningkatkan kemampuan membaca, Speed Reading adalah jenis membaca yang mengutamakan kecepatan untuk mengelola secara cepat proses penerimaan informasi dengan tidak meninggalkan pemahaman terhadap aspek bacaan.13 Nurhadi menyatakan "membaca cepat dan efektif ialah jenis membaca yang mengutamakan kecepatan, dengan tidak meninggalkan pemahaman terhadap aspek bacaannya". Muchlisoh mengatakan bahwa: Membaca cepat bukan berarti jenis membaca yang ingin memperoleh jumlah bacaan atau halaman yang banyak dalam waktu yang singkat. Pelajaran ini diberikan dengan tujuan agar siswa sekolah dasar dalam waktu yang singkat dapat membaca secara lancar dan dapat memahami isinya secara tepat dan cermat. Jenis membaca ini dilaksanakan tanpa suara.

Ada beberapa manfaat membaca cepat diantaranya: (1) Membaca cepat bisamelatih kecepatan mata dalam melihat (2) Membaca cepat didalam hati membuat siswa menjadi lebih fokus terhadap bacaan yang sedang dibaca (3) Membaca cepat dapat diterapkan saat membaca dengan keadaan terburu-buru sehingga titik 
fokus hanya pada ide pokok. Kelebihan metode Speed Reading antara lain : (1) Siswa dapat mengenali topik yang sedang dibaca dengan cepat dan tepat (2) Siswa dengan muah menyelesaikan bacaan hingga siswa memiliki rasa ingin tau terhadap bacaan yang lain. (3) Siswa dapat membaca dan menyimak dengan seksama sehingga sangat memudahkan siswa untuk cepat mendapatkan informasi/ide pokok dari suatu bacaan dengan melibatkan penglihatan, penghayatan serta ingatan. (4) Metode Speed Reading dapat dengan mudah diterapkan di berbagai sumber bacaan seperti majalah, buku, surat kabar serta pada saaat presentasi menggunakan Microsoft power point. Sedangkan kekurangan dari metode Speed Reading ini siswa hanya fokus pada ide pokok tapi meninggalkan bacaan lain sehingga siswa belum dapat memahami seluruh isi bacaan yang mengakibatkan siswa belum menguasai keterampilan membaca

- Penerapan Metode Speed Reading dalam Membaca Teks Drama

Langkah-langkah dalam membaca cepat antara lain : (1) Bacalah kata yang dirasa penting dan mencakup keseluruhan isi dari bacaan, misalnya judul dengan sub judul. Tafsirkan sesuai dengan imajinasi serta pengalaman yang telah dialami (2) Selalu perhatikan terlebih dahulu tentang keterangan gambar dari bacaan yang sedang dibaca (3) Baca kata yang diperlukan saja, didalam satu kalimat hanya ada satu ide pokok yang berada di kalimat utama pada paragraf masing-masing (4) Pikirkan kembali informasi yang telah diterima dari bacaan. Pada tahap ini siswa telah memahami isi bacaan dan telah mendapatkan informasi yang dicari, (Uzer, 2016).

\section{- Pembahasan}

Metode Speed Reading merupakan metode untuk meningkatkan kemampuan membaca pemahaman. Latar belakang pengetahuan yang dimiliki seseorang sangat memengaruhi proses dan hasil membaca. Hal ini memperkuat pernyataan Rahim (2011: 44) bahwa dengan menggunakan Metode Speed Reading siswa dapat menghubungkan pengetahuan yang telah dimiliki sebelumnya dan memiliki tujuan membaca yang jelas. Untuk pembelajaran membaca pemahaman di SMPN 16 Palembnag, Metode Speed 
Reading merupakan strategi yang baru. Pembelajaran membaca pemahaman yang selama ini dilakukan hanya dengan strategi yang konvensional yaitu dengan ceramah dan pemberian tugas pada siswa untuk membaca wacana. Pembelajaran seperti itu ternyata kurang mendapat respon positif dari siswa. Masih banyak siswa yang kurang antusias dengan pembelajaran. Berdasarkan data hasil dari penelitian ini, ternyata Metode Speed Reading mampu meningkatkan kemampuan membaca pemahaman. Peningkatan tersebut cukup berarti, baik dari segi proses maupun hasil. Dari segi proses, Metode Speed Reading ternyata mampu menarik perhatian siswa. Siswa terlihat lebih antusias dalam pembelajaran. Faktorfaktor yang mempengaruhi kegiatan membaca pemahaman seperti, sulit memahami wacana karena banyak kosakata yang tidak tahu maknanya dan menganggap sulit terlebih dahulu terhadap pembelajaran membaca pemahaman sudah bisa di atasi. Selain itu, secara keseluruhan peran aktif siswa juga lebih meningkat meski terdapat satu atau dua siswa yang kurang aktif. Dilihat dari segi hasil (produk), jelas terlihat bahwa jumlah siswa yang hasil belajarnya telah memenuhi standar KKM meningkat dari pratindakan hingga siklus II. Pada saat pratindakan terdapat 5 $(23,81 \%)$ siswa yang memenuhi standar KKM, pada akhir siklus I meningkat menjadi $16 \quad(72,73 \%) \quad$ siswa yang memenuhi KKM. Pada akhir siklus ॥ terjadi peningkatan lagi yaitu 22 $(95,65 \%)$ siswa telah memenuhi KKM. Hasil penelitian ini memperkuat pernyataan Johnson dan Pearson (dalam Zuchdi, 2008: 23-24) bahwa faktor yang berasal dari dalam diri dan faktor yang berasal dari luar pembaca dapat mempengaruhi terhadap kemampuan membaca pemahaman. Lebih lanjut, hasil penelitian ini juga selaras dengan pernyataan Paul D. Leedy (dalam Soedarso, 2005: 120-121) yang mengemukakan beberapa tujuan membaca pemahaman. Tujuan tersebut antara lain: untuk mengerti ide pokok, mampu memahami fakta dan detail khusus, meningkatkan kekayaan pengetahuan umum, dan mendapatkan informasi tentang apa yang terjadi di dunia.

\section{SIMPULAN}

Dapat disimpulkan yakni dalam proses pembelajaran menggunakan metode Speed Reading siswa 
mengalami peningkatan dalam membaca tanpa harus mengalami kesulitan. Selian itu, kemampuan menyimakpun terdapat peningkatan, karena dengan adanya peningkatan dalam menyimak, siswa akan konsentrasi dalam pembelajaran membaca teks drama. Keterampilan membaca, menyimak serta membaca cepat merupakan satu 'kesatuan yang sulit dipisahkan' karena saling 'terkait satu dengan yang lain. Didalam keterampilan membaca cepat siswa juga harus dapat menyimak dengan baik terkait isi teks drama yang ada didalam suatu bacaan

\section{DAFTAR PUSTAKA}

Abdurrahman, H. (1996). Pendidikan bagi Anak Berkesulitan Belajar. Jakarta. Rineka Cipta Arikunto, S. S. (2009). Penelitian Tindakan Kelas. Jakarta.

Dalman. (2014). Keterampilan Membaca. Jakarta. Raja Grafindo.

Dewantara, D. \&. (2015). Bahasa Indonesia Keilmuan. Undiksha Press.

Fuady, A., Sumarwati.. \& Mulyono, S. (2012). Pembuatan peta semantik pada kegiatan prabaca untuk meningkatkan kemampuan memahami bacaan siswa sekolah menengah. Journal Pendidikan Bahasa, Sastra Indonesia dan Pengajarannya. (1)

Hariyanto, S. \& (2011). Belajar dan Pembelajaran. Bandung: PT Remaja Rosdakarya.

Nurgiyantoro, B. (2010). Penilaian Pembelajaran Bahasa Berbasis Kompetensi . Yogyakarta: BPFE.

Madya, S. (2009). Teori dan Praktik Penelitian Tindakan: Action Research. Bandung. Alfabeta.

Rahim, F. (2008). Pengajaran Membaca di Sekolah Dasar. Jakarta. Bumi Aksara. (2011). Pengajaran Membaca di Sekolah Dasar. Jakarta. Bumi Aksara.

Slamet. (2009). Kemampuan Membaca Pemahaman Mahasiswa. Jurnal Paedajogia, 118129.

Soedarso. (2005). Speed Reading Sistem Membaca Cepat dan efektif. Jakarta. Gramedia Pustaka Utama. 
Tarigan, H.G. (2008). Membaca Sebagai Suatu Keterampilan Berbahasa. Bandung. Angkasa.

Uzer, Y. (2016). Penerapan Teknik Quantum Speed Reading dalam Pengajaran Pemahaman Membaca. Wahana Didaktika.

Widyaningrum, R. (2019). Upaya Meningkatkan Kemampuan Menulis Tegak Bersambung Melalui Contoh di Buku Halus dan Drill pada Peserta Didik Kelas I SDN Jajartunggal III Surabaya. Trapsila: Jurnal Pendidikan Dasar

Zuchdi, D. (2008). Strategi meningkatkan Kemampuan Membaca Peningkatan Komprehensi. Yogyakarta. UNY Press. 